\title{
Breast Cancer pN1a TNM Finding v8
}

National Cancer Institute

\section{Source}

National Cancer Institute. Breast Cancer pN1a TNM Finding v8. NCI Thesaurus. Code C139435.

Breast cancer with metastases in 1-3 axillary lymph nodes, at least one metastasis larger than $2.0 \mathrm{~mm}$. (from AJCC 8th Ed.) 